H.J

1516

$\frac{1516}{25 c 8}$ c.

(5)
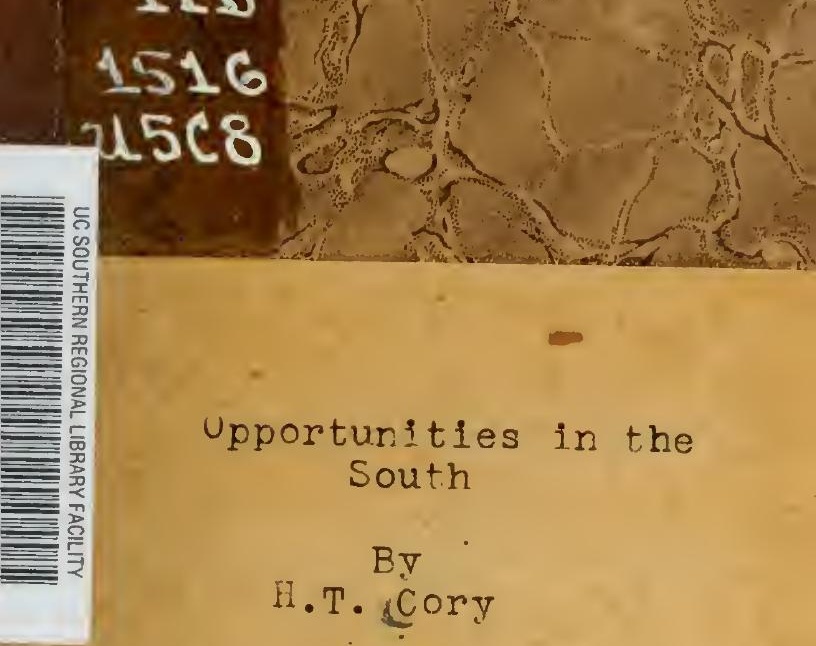

Upportunities in the
South

$$
\text { H. T. B Cory }
$$

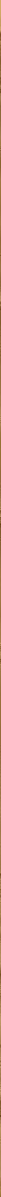




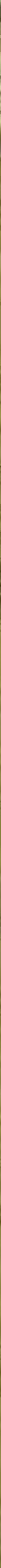




\title{
OPPORTUNITIES IN THE SOUTH
}

Address Delivered Before the Southern Land Congress

November 12, 1918

\author{
BY \\ H. T. CORY \\ CONSULTING ENGINEER
}

UNITED STATES RECLAMATION SERVICE

WASHINGTON, D. C.






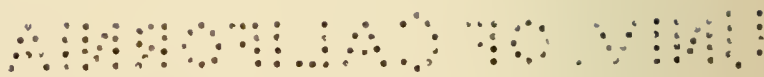

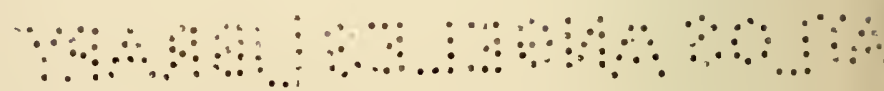




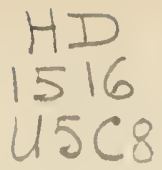

\section{Opportunities In the South}

["The national importance of the remarkable statements made in the following article is emphasized by reason of Mr. Cory's pre-eminence in the engineering world, and by the fact that he is not now and never has been identified with the South or with Southern development. Born in the West and living in California, Mr. Cory has been making for the United States Reclamation Service of the Department of the Interior a comprehensive study of the resources and advantages of the South. The statements which he makes in regard to the South should, therefore, be studied in the light of the fact that they are not made by a Southern man, or one who has ever been identified with Southern activities."-Editor Manufacturers Record.

The press throughout the country has similarly endorsed and advocated the plans of Secretary of the Interior Franklin $\mathrm{K}$. Lane and his associates. Mr. Cory is in charge of investigation in the South.]*

\section{Mr. Chairman, Ladies and Gentlemen:}

I am convinced that a very large minority, if indecd not half, of the returning soldiers for whom it is planned to make provision, could be taken care of in the coastal plain of the South. Here, I am convinced, are the cheapest lands adaptable to agriculture in the entire country-all things considered.

The other sections of the Southern district which is bounded on the north, roughly speaking, by the Mason and Dixon Line, the Ohio River, and including Arkansas and Oklahoma and Eastern Texas, and on the west by the 9 Sth Meridianoffer additional and important opportunities.

While in no wise failing to appreciate the advantageous conditions existing in such sections

*[From Who's Who-1918-1919.-Cory, Harry Thomas, Engineer; born Lafayette, Ind., May 27, 1870 . B.M.E., Purdue Úniversity, 1887; B.C.E., 1859. M.C.E., Cornell, 1893; M.M.E., 1896. Assistant Engineer A. \& M. Railway, 1888; Assistant City Engineer, Lafayette, Ind., 1889; Deputy County Engineer, Tippecanoe county, Indiana, 1890-2; Professor Civil Engineering, University of Missouri, several years, from 1893; in Europe, 1898; Professor Civil and Sanitary Engineering, University of Missouri, 1898; Dean Engineering Department and Professor Civil Engineering. University of Cincinnati, 1900-3; on leave of absence from University of Cincinnati, 1901-3, with Mexican Central, Texas \& Pacific and Southern Pacific Railroads; Assistant to General Manager Southern Pacific Co., July, 1904; May 1905. In persoanl charge of diverting Colorado River from running to Salton Sea, 1906-7; Assistant to President associated Harriman lines in Arizona and of Southern Pacifio Railroad in Mexico, May, 1905; July, 1910. General Manager and Chief Engineer of the California Development Co. and La-Sociedad de Riego y Terrenos de la Baja California, 1906-July, 1910. Consulting Engineer at San Francsico, July, 1909. Author-Imperial Valley and Salton Sea, 1915; Manual of United States System of Land Surveying, 1888; also Atlasse of Boone (1888), Clay (1890) and Tippecanoe (1892) counties, Indiana; also technical reports, scientific papers and magazine articles. Member American Society Civil Enginecrs (Thomas Fitch Rowland prize, 1914). American Society Mechanical Engineers. HomeBerkeley, Cal, Office-Nevada Bank Building, San Francisco.]




of this Southern district, I will confine myself today to the coastal plain. I do this because I was myself so surprised by the magnitude and extent of the opportunities for the work in hand, that it may be profitable to here consider how such a condition of affairs came to pass.

\section{Psychology of the Trend in American Colonization.}

The American people, like all others, have their actions largely determined by ideas generally current. In other words, they, like other human beings, tend to follow like sheep the way they get headed. Since the Civil War the trend of emigration has been westward; it is still; and it will continue to be so for a considerable period, unless it is broken up by some very decided and spectacular activity. The colonization movement southward up to this time has been relatively very small indeed.

The chief reasons for this are:

1. The generally accepted expression-all but a proverb- "Go West, young man, and grow up with the country," coupled with enormous areas of free government lands in the Western States. The part which the existence of free government lands played in starting the trend of emigration westward was set forth yesterday by the Hon. Clay Tallman, Commissioner of the General Land Office, and set forth very clearly indeed. The practical result of the expression "Go West, young man, and grow up with the country," is vastly greater than people generally realize. It is a part of what might be called the psychology of the times and situation. This psychology involves a number of other things, but really comprises habits of thought.

To digress a little at this point, it may be proper to point out that the habits of people very often profoundly affect the prosperity of a region. An excellent example of this is the continuation of the South in raising cotton, corn and tobacco until the lands are so impoverished that poor crops become the rule, instead of practicing diversified agriculture. Another instance is the psychology of the German people, which throughout the past three or four years, has been a constant source of amazement to America and a great part of the rest of the world. Illustrations like these could be given almost without limit. 
2. The widespread impression that the sentimental difference between the North and the South during the war tend to make newcomers from other sections uncomfortable. This impression has its foundation more in the reconstruction period than in the war period, and has been a very important factor in this whole matter.

3. A very general misconception of the negro problem.

4. The somewhat subconscious feeling that the South is unhealthy because of the yellow fever epidemics prevalent some years ago. This again is really a matter of psychology, because, while epidemies of many kinds passed over the United States, the yellow fever epidemics were sectional in character, and about the only very serious ones which have been confined to a definite section of the United States.

5. The vague feeling that the long summers and short winters generally constitute climatic conditions tending-in a long period of yearsto slow undermining of aggressiveness and enterprise. This again is a matter of psychology and based only upon the general impression of results achieved in commercial, industrial, and, to a less extent, agricultural development.

6. The existence after the Civil War of enormous forest areas in the Atlantic and Guif Coastal plains region and to a much less extent in the Piedmont sections. There was an enormous stretch of pine forest reaching from Norfolk, Va., to Galveston, Texas, and extending back well into the Piedmont regions.

\section{Critical Analysis of Such Psychology.}

As a matter of fact, none of these separate elements constituting the entire psychology of the situation will bear critical examination. The movement westward has resulted in agricultural land values in the far west really higher-every thing considered-than elsewhere in the country. Then it turned to the North and 950,000 Americans went over into Canada in the great settlement movement of the Canadian northwest. There are a few sporadic instances of the trend turning backward, and, doubtless, it will continue to inerease more and more. Nevertheless, the development of the North and West continues at a 
greater rate than that of the South, and this means opportunities for greater advancement--not necessarily greater opportunities for advancement. Consequently the attractiveness of the North and West for ambitious people continues to the disadvantage of the South and such movement of the ambitious people carries along other types which follow rather blindly, and without much thought.

Concerning the second point, the Southern people, whose opinions are really worth while, welcome new blood and new capital. Indeed, it is not too much to say that the South really welcomes the newcomers about as much as the Westwith less enthusiasm and spirit of inspiring hopefulness, perhaps, but with more hospitality.

The negro problem in many ways is solving itself. Those of us who have really had personal contact with it know that the Southern people understand the negro problem better than the rest of the nation, and that general public sentiment in the South calls for essential economic justice to the negro.

I was very much impressed-in this connection -with the attitude of some Northern and many Southern people with whom I have discussed the matter of provision for negro soldiers and sailors who return from the war. About half the Northern people doubted the practicability or wisdom of making any provision for such colored soldiers. On the other hand, I did not meet a single Southern man who did not emphatically say that returned negro soldiers should have equal consideration in the proposed policy of Secretary Lane as the white soldiers. Many times Southern men have reminded me of the fact that there are negroes and negroes, just as there are white people and white people, and in both cases there were some deserving and some underserving people. The opinion was almost unanimously expressed by the Southern man that the negroes should be segregated and kept to themselves, but the unanimity was absolute as to making full provision for the returned negro soldier and sailor.

There is a sort of inchoate, vague, but none the leas persistent, abstraction in the minds of Northern and Western people that in the Southland the negroes do the manual labor and by that token practically insure a lower social caste for the white worker. I was quite surprised by the impression gained on my trip that there are no greater 
social distinctions in the South than in the West based upon the classification of whether people do manual labor or not. There is a social distinction between the laboring classes and other classes, in the South, but believe me, there is also a similar distinction in the West and in the North.

It is now known, and has been for a few years, that yellow fever and malaria are mosquito-borne discases and that the mosquito is eliminated by proper drainage. This fact has made it practical to remove any disadvantage in the South with respect to health. It must in all fairness, however, be said that actually such disadvantages have not been removed as yet. When the mosquito has been largely eliminated, the South ought to be healthier than much of the remaining United States.

In passing, it may perhaps be desirable to note that the hookworm is almost exclusively confined to the South, but that is a matter of social conditions, and environment which obtains in but a small section of the South, and has no bearing upon the health of the Piedmont and Coastal Plain regions.

The impression that long continued residence in a warmer climate reduces individual aggressiveness, initiative and energy is a quite general and persistent one. It is entirely untenable, however, at least so far as the climate of practically all the Southern States is concerned. The slowness of development in the South is an unfortunate after-effect of the Civil War and a few other transient conditions.

Fortunately, the assignment of large numbers of soldiers from all parts of the country to Southern cantonments has educated very many Northern soldiers and sailors pretty thoroughly as to Southern climatic conditions.

In the past two decades enormous areas of pine forests have been denuded of their merchantable timber, and the lands are now available for clearing and are now ready for agricultural uses.

\section{Desirability of Changing the Direction of Emigration.}

The present war has shown very forcefully the desirability of a more scattered industrial and manufacturing population. In the recent period of war, stress transportation facilities and other 
essential elements of industrial and manufacturing production, broke down. The more thoughtful people realize that considerable change is highly desirable.

The sharp rise in food prices which began before the present war indicates the desirability of using for agricultural purposes the areas best suited for cheap food production. Perhaps it would be more correct to say that the desirability was shown for using agriculturally the areas best suited for maximum food production given man-power.

The South is nearer to the dense population along the upper Atlantic coast than the West, and has cheap water transportation.

For these and other less important reasons it is to the national interest to divert colonization southward, so far as that can be done without running afoul of population ambition and, perhaps, political antagonism of other sections of the country.

\section{Forestation vs. Agriculture.}

It has been urged that forest lands be, so far as possible, continued in timber. There is much to be said in favor of this view. Personally, I am convinced that the agricultural output of the country is not so much a matter of available agricultural land as it is of agricultural labor; that if all the available agricultural labor in the country were concentrated on one-half of the areas now cultivated, a greater amount of food would be produced, and with better social conditions at a less unit cost; that an increase of cultivated area iswith available agricultural labor-not only unnecessary, but really undesirable; that the forest areas of the United States should, on the other hand, be increased; and that from an abstract point of view the best uses of the cut-over lands of the South would be reforestation.

As a matter of fact, however, the practical working of that sort of thing would be permanently to keep vast areas of the South with a very small population. This seems to me to be penalizing the South because of the transicnt condition in which it happens to be at a time when a totally new segregation of lands for various purposes is suggested. The discrimination against the South which would result from changing the forest policies just at this time impresses me more and more with 
its unfairness to the region and its undesirability from a national point of view.

It would seem fairer that the Southern cut-over lands having the best soil be cleared and put to agricultural use and that the poorer areas of Ohio, Indiana, Illinois, Iowa, etc., be segregated and returned to forestation. In other words, I would distribute the cultivated and forest lands on a somewhat equitable basis over the whole United States and not saddle a disproportionately large forest area on the South to the permanent disadvantage of the Southern States.

The ideal thing would be a careful survey of the whole United States and a classification and segregation of lands everywhere, to the end that the proper cultivated area and the proper forested area should be secured, and that the agricultural areas should be those best adapted for the purpose, and the remainder devoted to forestation. For some time to come this is probably out of the question, but it is very unfair to the South, just at this stage, to stop the old regime-to change the rules of the game after the cards are dealt, as it were-and say that all the lands not now under cultivation which will grow trees should be continued as forests.

\section{Ability to Turn the Tide of Colonization Southward.}

Assuming that the foregoing line of reasoning is accepted and that it is desirable to turn the tide of Anierican colonization southward, the next question is can it be done, and if so, how.

It probably can be done, but if so, due weight is to be given to the following:

1. The population of the United States is not growing as rapidly as it did some years agospeaking relatively rather than absolutely. Since 1914 this has been quite marked, of course because of the world war. In a general way, however, this country is beginning to share with France, Germany, and the most advanced countries in the world in a decreased birth rate. The birth rate in Germany for example dropped 40 per thousand in 1885 to 18 in 1912. This condition of affairs is contrary to the general understanding as to the increase of German population.

2. Immigration will doubtless continue to this country and tend to bring westward the center 
of the world's population, but the total manpower growth in this country from this source for the next one or two decades at least will be considerably less than heretofore.

3. Consequently the growth of the South, so far as agricultural labor is concerned, even though it should keep pace with that of other sections of the United States, would not be very rapid-not rapid enough at least to absorb the agricultural possibilities of the cut-over timber lands alone for a long time.

4. Therefore, the South needs and should have a greater influx than the country in general. This means that some positive and spectacular stamp of approval must be placed upon the region by an authoritative agency, so that the unfortunate psychology existing in the rest of the United States respecting the South be shattered.

5. If the National Government should establish three or four colonies in each of the Southern States and place its stamp of approval upon them, saying that it recommends them as homes for its returning heroes as freely as it recommends colonies in any other State of the Union, such action would go far toward breaking up this unfortunate attitide vastly farther than any other thing of which I can think.

6. In addition to placing the Government's blanket stamp of approval on such Southern colonies, as distinct from approving its soil conditions by one Government bureau, its climatic conditions by another bureau, and its crop production by still another bureau, etc., is the fact that something like as great publicity would be given to the Southland as has been given to the Western sections from the work of the Reclamation Service in the arid regions. The Southland has never had anything like the systematic advertising of the West.

For example, about ten days ago a party of four of us sat down to dinner in the cafe of the Hotel Wilmington, in Wilmington, N. C. On the bill of fare were five California products set forth, as such, three of them right down the line, as follows: New California lettuce, new California celery, new California tomatoes; the other two were California olives and California prunes. Investigation was instituted by one of the party, who was nettled, 
and I was later informed that as a matter of faet, neither the lettuce, celery nor tomatoes came from California, but from the South. Ponder carefully upon the psychology right in your inidst that such a thing should oceur within a few miles of Mr. Hugh MeRea's colonies, which ship north large amounts of truek.

The plain fact is the South needs advertising -not of its possibilities, but of its output. Descriptions of each of the many United States Reclamation Service irrigation projects in the West have appeared in all kinds of popular, seriousand technical journals to such an extent as to alone constitute a very important amount of advertising. This has indirectly resulted in other articles about the general region, having a total advertising value of almost equal extent.

It is always the spectacular things about which people most read. What could be more dramatic than the magieally rapid transformation by returning soldiers of Southern swamps, wet lands, and cut-over lands into the very highest and best type of rural communities which it is possible to plan?

All the colonies should be large models of rural communities for any region and commereial demonstrations of Southern agricultural possibilities, and they should be well seattered over the South. They should immediately cause surprise and admiration on the part of motorists traveling the Dixie highways, and induce the most favorable comparisons with the best types of agricultural development in the country

The soldier colonists will be very closely knit together, having shared the same dangers and privations, many months of rigid discipline, and all having a thorough understanding of the value of co-operation-something very lacking in the average farmer. They would not mix very generally with neighbors outside of the colonies with different standards of living. Therefore, the personal reactions would be inward and toward the co-operative type of farm life.

All the colonies would also have a great deal of influence, for it is quite probable that men now wearing the khaki and the present associates of the future colonists will shortly very largely dominate both in the state and the national governments. 
Such colonies would really constitute centers of infection or innoculation, and do more to standardize the business of farming in a decade than has so far taken place in the entire history of the country.

\section{Location of Colonies in the Southland.}

Roughly speaking, the Atlantic and Gulf Coast States may have their combined areas divided into three gencral classes, the mountainous, the Piedmont, and the Coastal Plain sections. The mountainous sections are not adapted to agriculture, with the exception of a relatively small so-called Thermal Belt, which is peculiarly adapted to fruit culture.

The Piedmont section was put to agricultural uses first, because a smaller amount of clearing was required; the soil appealed to the early colonists; and health conditions were generally better, owing to few mosquitoes. Consequently, the Piedmont section, speaking by and large, is well cultivated, the holdings are relatively small, and the average price per acre is fairly high. It contains most of the larger towns and practically all of the manufacturing industries.

Therefore, most of the opportunities in the South worthy of consideration in connections with colonies for returned soldiers and sailors are in the coastal plain, which begins at Norfolk, Va., and extends to Galveston, Texas. In this area there are, roughly speaking, below the 100 -foot contour along 88,000,000 acres of land. Practically almost all needs drainage of a more or less important character.

Speaking broadly it can be said that a very large part of this area consists of fertile soil well adapted to general agriculture and corresponding to the majority of good lands in Indiana and Ohio, the cropping season is much longer, and the period during which live stock would have to be fed very much shorter. Hence, with a given amount of encrgy greater returns may be secured per acre and per man-day than in all but the most fertile sections of the entire country.

Of the many million acres of such lands suitable for the purposes at hand it is easily possible to have several colonies ranging from 75,000 to 300,000 acres in size scattered over the coastal plain, and with a total acreage in each of the 
Atlantie and Gulf plain States of from 500,000 to $1,000,000$ acres. Generally speaking, the actual cost to the colonist of going-concern farms, such as hereintofore outlined, would be around $\$ 80$ to $\$ 100$ per aere. Of this amount-speaking generally - the costs of the land and of the drainage therefor, will about equal each other and together be about one-half the cost of clearing, stumping, plowing, and putting in the first erop. Roads, fences, buildings, ete., will be about one-third of the total investment.

What has hitherto been a serious problem in the coastal plain-the very large holdings of landis here a great advantage. With holdings of 50,000 acres in a single body-by no means uncommon thing-the obtaining of large colony areas from private owners is enormously simplified.

The investigations of land areas in the South have not ealled for elaborate and detailed studies. The areas of lands which can be developed for the purpose herein outlined are so many and so large that attractive sites for as many eolonies as may be desired can certainly be seeured. Essential data are available at this time for many. A considerable number have been personally inspected. Therefore, there is no reason to doubt the ability to sccure such as may be required and at a fair price.

\section{The General Program.}

So much for my idea of the relationship of the general proposed program to the territory assigned to me. Now a few words as to the general plan itself.

But for the enormously important and bewilderingly rapid international developments of the past few days, the Secretary of the Interior, the Hon. Franklin K. Lane, would have been here and outlined the general program to be presented to Congress. Under the cireumstances, therefore, it seems desirable that there should now be set forth, briefly and in general terms, what it is planned to do.

This is to-

(1) Make suitable and worthy provision for such of the returning soldiers and sailors as may desire rural life and occupations, and along the 
general line followed by many other governments. Congress will be asked to pass the necessary legislation and make ample appropriations to this end.

(2) Enact legislation which will specifically provide for the part that the National Government, the part that the States' governments, and the part that private land owners should perform.

(3) Further, the several State governments will be asked to pass and repeal such legislation, if such action be necessary, to enable the respective commonwealths to make effective the proposed national legislation.

These laws taken in combination will provide the machinery for carrying out in this country the general methods which have already been found successful in other countries and in a few States of our own country. They are along the general lines of the ideas presented to this congress and indorsed by a unanimous resolution thereof.

\section{Conclusion.}

Summing up briefly - there are four fundamental factors which must govern any successful large movement for placing our returning soldiers upon the land. They are:

1st. Providing for a class of settlers almost wholly without capital.

2nd. Creation of model communities with such attractions and comforts that the soldier with only a small equity will work to retain it. Certainly no less should be done for the soldier than has been done for the employee in ship building or munition plants.

3rd. Establishment of colonies large enough to develop community spirit and enterprise, and compact enough to eliminate loneliness and isolation.

4th. Provision for each colony of advisers who are competent and experienced, to carry the settler through the formation period of the first three years. These will be found among their own comrades.

5th. The opportunities for such colonies in every State in the Union can doubtless be found, and certainly exist, in profusion in the South coastal plain. 

This book is DUE on the last date stamped below

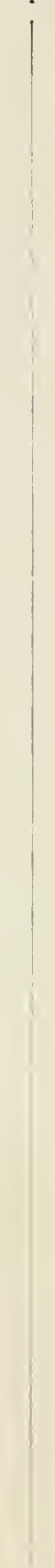

UNIVLKSII I OT WAIIFORNIA A'

LOS $A^{\wedge}+$ LES

LIBRAIIY 
